\title{
Comparative Analysis of Electrophoretic Profile of Major Proteins of Milk from Alpine and Carpathian Goats
}

\author{
Alina NĂSALEAN ${ }^{1}$, Laurenţiu OGNEAN ${ }^{1}$, Sergiu MUNTEAN ${ }^{1}$, Ştefana BÂLICI ${ }^{2}$, Horea MATEI ${ }^{2,3}$ \\ ${ }^{1}$ Department of Physiology, University of Agricultural Science and Veterinary Medicine, Cluj-Napoca, \\ Romania \\ ${ }^{2}$ Department of Molecular Sciences, Faculty of Medicine, "Iuliu Haţieganu" University of Medicine and \\ Pharmacy, Cluj-Napoca, Romania \\ ${ }^{3}$ Institute of Legal Medicine, Cluj-Napoca, Romania \\ *corresponding author: lognean@yahoo.com
}

Bulletin UASVM Veterinary Medicine 74(1) / 2017,

Print ISSN 1843-5270; Electronic ISSN 1843-5378

DOI:10.15835/buasvmcn-vm: 12447

\begin{abstract}
The milk's proteins provide nutritional and biologically active values, essential in human and animal nutrition. In the case of goat milk, the proteins' concentration and quality represent important indices for the evaluation of the nutritional and biologically active values. The aim of this study was to comparatively analyze the proteins profile in goat milk from two different breeds: French Alpine and Romanian Carpathian. The milk samples were collected during March and April 2016, in hygienic and sanitation conditions. The proteins profile of goat milk was establish using SDS-PAGE electrophoresis, after the evaluation of the total proteins' concentration with the Bradford method. The quantitative and percentage data obtained in electrophoresis revealed few differences between identified proteins. In the case of breeds studied has been noted significance differences in terms of the three major proteins in milk - $\beta$-CN, k-CN and $\beta$-lactoglobulin. The other protein fractions have almost identical values. This study brings new contributions in the evaluation and analysis of goat milk protein profile as a nutritive and biologically active component, confirming its character as a functional aliment.
\end{abstract}

Keywords: goat, milk, proteins, SDS-PAGE

\section{INTRODUCTION}

Milk is a very important functional aliment, characterized by a special protein composition, with important physiological functions, such as binding calcium, iron and other minerals. This property can subsequently induce antimicrobial, antihypertensive, antioxidant and immunomodulatory effects (Korhonen and Pihlanto, 2001, 2009; Roncada et al., 2012; Murata et al., 2013).

Proteins in milk ensure nutritive and biologically active values, which are essential for human nutrition (Drewnowski and Fulgoni,
2008). In the case of goat milk, the concentration and quality of the proteins are basic indices in the evaluation of the nutritional and biologically active value. As it is well known, these parameters show differences due to a series of intrinsic factors (milk's morphological particularities) and extrinsic factors (breed, diet, geographical area) (Năsălean et al., 2015)

The use of goat milk in children's and small animals' diets, as a source of proteins, has significantly increased in recent years especially as an alternative to cow milk, which contains specific proteins frequently involved in hypersensitivity 
reactions (Santos et al., 2010). It is also known that these hypersensitivities are one of the major causes of food allergies (Drewnowski and Fulgoni, 2008; Korhonen 2009). Goat milk stands out due to the presence in its composition of easily digestible lactic compounds with important metabolic properties for human alimentation (Vargas et al., 2008).

Compared to cow milk, goat milk proteins are more easily digestible (Ceballos et al., 2009), amino acids resulting from the hydrolysis are more rapidly, and more efficiently absorbed (Gill et al., 1990). The protein fractions in goat milk are qualitatively similar to those found in cow milk. The differences are given by the quantity of casein, especially $\alpha$-casein (Vargas et al., 2008) and by a much higher level of essential amino acids (Haenlein, 2004). The low allergenic level of goat milk (Ballabio et al., 2011), compared to cow milk, is due to the complete absence or the presence in low levels of $\alpha$ s1-casein, a protein which is considered to be responsible of allergenic potential (Olalla et al., 2009).

The quality of the milk, from a sanitary perspective (Ognean, 2001) and as a nutritional, biologically active value is considered essential for the welfare and safety of the consumer (Michel, 2001; Yadav et al., 2014). Thus, goat milk's unique composition, combined with its nutritional value is linked to the release of protein fragments during digestion or during technological processing, that are capable of specific biological activities (Park et al., 2007). Because there are a limited number of studies (Hinz et al., 2012) regarding the evaluation of the proteins profile in milk from different breeds of the same species, the purpose of our study was a comparative assessment of proteins profile in two different mountain breeds, with similar breeding and feeding regimes. All these can support the correlation between the pronounced polymorphism of caseins with a low allergenic level and an important nutritional value. The characterization of the proteins in goat milk can lead to improved breeding, increasing the use of goat milk in human diets (Ballabio et al., 2011; Hinz et al., 2012).

\section{MATERIALS AND METHODS}

The research was conducted during MarchApril 2016, on milk samples collected from 2 different breeds: lot I - Carpathian goats $(n=10)$ and lot II Alpine goats $(\mathrm{n}=10)$. There were selected clinically healthy animals, from a livestock of a micro farm with 60 goats. Those animals were predominantly feed by grazing and maintained under traditional conditions. From every lot, there were collected samples of raw milk, twice per month. The sampling procedure strictly complied with the conditions of hygiene and sanitation, using sterile sampling bottles.

Proteins composition of goat milk was established using Polyacrylamide Gel Electrophoresis with Sodium Dodecyl Sulfate (SDS-PAGE) method. In addition, the concentration of total proteins was evaluated using Bradford method with some modifications (Bradford, 1976). All reagent and solvent used in our study were purchased from Sigma-Aldrich (Co. LLC., St. Louis, MO, USA).

Milk samples were centrifuged at $4000 \mathrm{rpm}$ for 30 minutes at $4^{\circ} \mathrm{C}$ and then they were left for 20 minutes, after that the lipid layer was removed. The skimmed milk samples were treated with clarifying reactive $(8 \mathrm{M}$ urea, $0.3 \%$ dithiothrietol dissolved into $1 \mathrm{~mL}$ of $0.1 \mathrm{M}$ TRIS buffer with $\mathrm{pH}=8$ ). A volume of $20 \mu \mathrm{L}$ skimmed milk was treated with $140 \mu \mathrm{L}$ clarifying solution, mixed for 10 seconds obtaining clarified milk solutions (CM), which can be stored for a long time at $-80^{\circ} \mathrm{C}$ (Andrei et al., 2012). From CM there were performed the determination of total proteins and their separation and identification (SDS-PAGE).

For the determination of protein were measured $20 \mu \mathrm{l}$ clarified milk, was added $500 \mu \mathrm{l}$ distilled water and $1480 \mu \mathrm{l}$ Bradford reagent and incubated for 5 minutes at room temperature. To sample was then added $1 \mathrm{ml}$ of distilled water and the absorption was determined at the wavelength $\lambda=595 \mathrm{~nm}$, using Specord S600-212C170 spectrophotometer (Analytik Jena, Germany) with WinASPECT software. The concentration was determined using a calibration curve obtained from a stock solution of bovine serum albumin (BSA) (Andrei et al., 2012).

The CM samples containing solubilized proteins, with a concentration of $1 \mu \mathrm{g} / \mu \mathrm{L}$, were denatured for 5 minutes at $95^{\circ} \mathrm{C}$ and after that were separated using a Mini-PROTEAN®3 Electrophoresis System (Bio-Rad, USA). In order to separate the proteins gels consisting of two different phases (stacking or concentration gel and running or separation gel) were used. The 


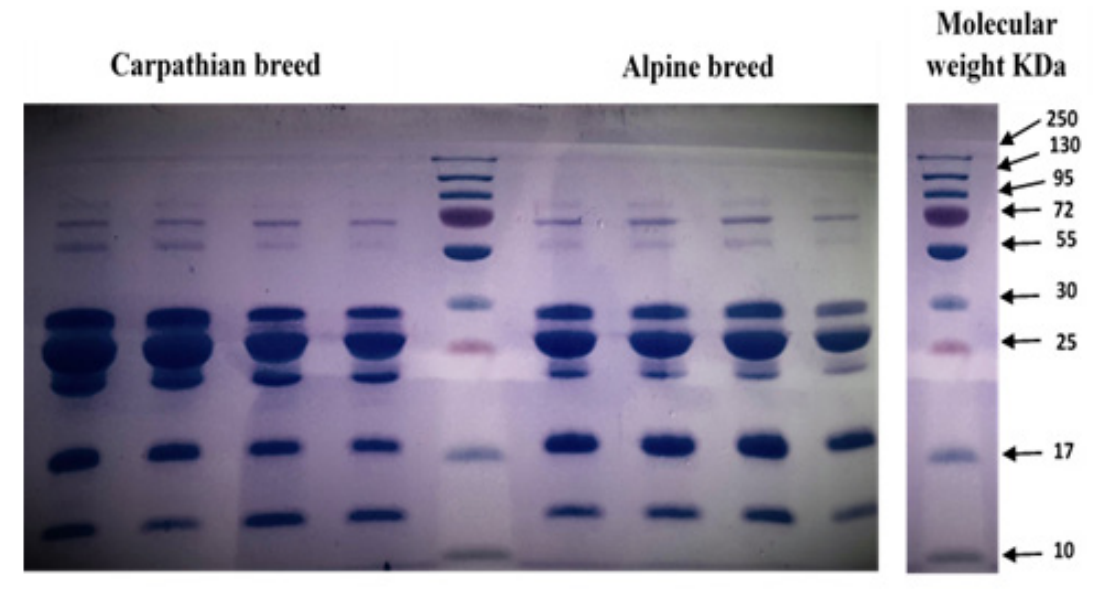

Fig. 1. The separation of protein fractions and the markers used in the identification

proteins migration it was carried out at $60 \mathrm{~V}$ in the concentration gel, respectively at $150 \mathrm{~V}$ in the separation gel. In order to estimate the molecular weight of the separated proteins, on the same gels was migrated in parallel a mixture of proteins, PageRuler Plus Prestained protein ladder (Thermo Scientific, Lithuania), with molecular weight between 10 and $250 \mathrm{kDa}$. After the separation, proteins were stained with BioSafe Coomassie blue G-250 Stain.

The stained gels were analysed through densitometry using Model GS-700 Imaging Densitometer (Bio-Rad, USA), and the different percentages of the display protein fractions on gel were calculated with Molecular Analyst Software (Bio-Rad, USA) and statistically analysed using GraphPad InStat and OriginPro Software.

\section{RESULTS AND DISCUSSION}

Figure 1 presents one of the gel obtained, being specified the type of the sample (corresponding to the breeds) and the standards used in the approximation of molecular mass of milk proteins separated.

Our data are consistent with data from the literature, according to which the migration of protein fractions and their separation are dependent on the molecular weight of proteins (in $\mathrm{kDa}$ ) and on the concentration of gel used in the separation (Andrei, 2006; Ceballos et al., 2009).

Figure 2 presents the main proteins of goat milk samples. Thus, the following major proteins were identified: lactoferrin (lactof), immunoglobulins (Ig), the caseins $\alpha$ s1-CN, $\alpha \mathrm{s} 2-\mathrm{CN}$,
$\beta-\mathrm{CN}, \mathrm{k}-\mathrm{CN}$, and the soluble proteins $\alpha$-lactalbumin and $\beta$-lactoglobulin.

Densitometric analysis of gels, followed by statistical analysis of the data obtained revealed some significant differences in the major proteins profile for the the two breeds (Table 1).

Thus, regarding lactoferrin, with molecular weight around $72 \mathrm{kDa}$, the recorded proportions werevery closefor the two groups $(0.7 \%$ for lot I and $0.8 \%$ for lot II). In contrast, the immunoglobulin, protein fraction with a molecular weight of $55 \mathrm{kDa}$ showed major changes, its values being nearly twice as high for the Alpine goats (4\%), than for the Carpathian goats $(2.7 \%)$. The third protein fraction isolated was $\alpha \mathrm{s} 1-\mathrm{CN}$, a protein with a molecular weight up to $25 \mathrm{kDa}$, which in this study was characterised by values almost equal in both races. In the case of the next fraction, $\alpha \mathrm{s} 2-\mathrm{CN}$, a protein with a molecular weight between 24 and $25 \mathrm{kDa}$ there were also recorded similar values.

The fifth identified protein fraction was $\beta$-casein, a protein with molecular weight of $23 \mathrm{kDa}$, which was characterised by the most important quantitative level. The evolution of this fraction showed significant differences between the races, $30.56 \%$ for the samples from lot I and $26 \%$ for those from lot II. The following protein fraction recorded was K-casein, with a $20 \mathrm{kDa}$ molecular weight, which, according to data, presented important differences, the recorded values being $15.4 \%$ for Carpathian goats, respectively $12.5 \%$ for the Alpine goats. The seventh protein fraction was $\beta$-LG, protein with molecular weight of 18 $\mathrm{kDa}$, in the case of which, between the recorded values there were significant differences, reaching 


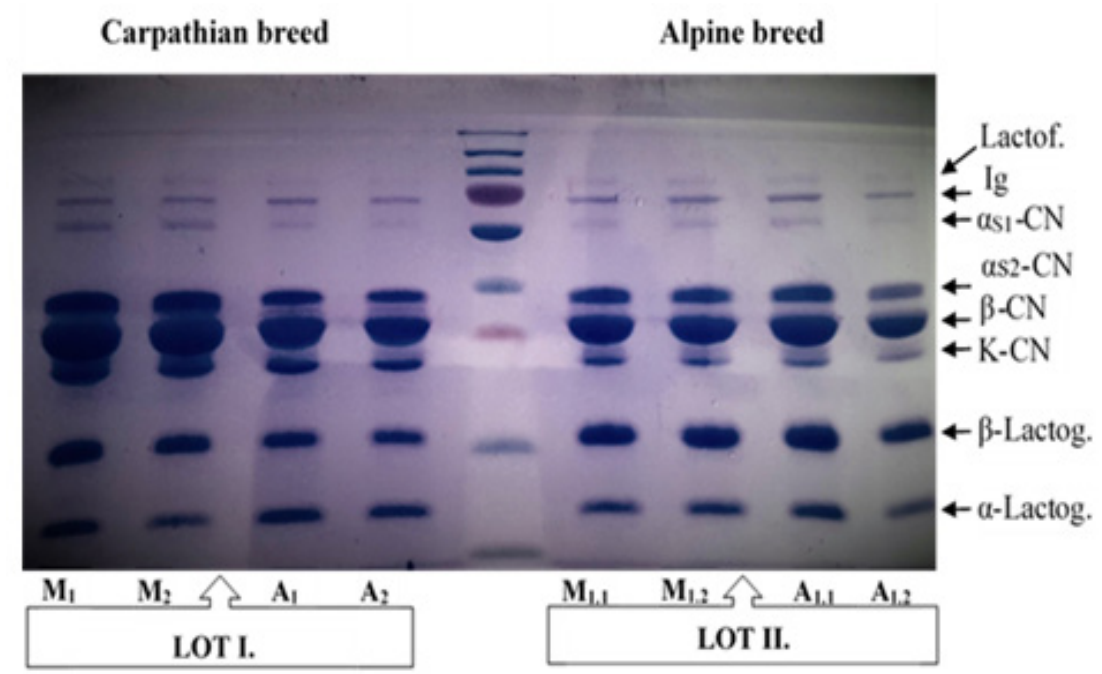

Fig. 2. The major proteins identified in milk samples

Tab.1. Composition (\%) of the principal classes of protein

\begin{tabular}{|c|c|c|c|c|c|c|c|c|c|}
\hline \multirow{2}{*}{$\begin{array}{c}\text { Statistical } \\
\text { parameters } \\
\text { of major } \\
\text { proteins } \\
\text { analysed }\end{array}$} & \multicolumn{9}{|c|}{$\%$ Protein (from the total proteins) } \\
\hline & lactoferrin & $\begin{array}{l}\text { Immuno- } \\
\text { globulin }\end{array}$ & $\alpha S 1-C N$ & $\alpha S 2-C N$ & $\beta-C N$ & $k-C N$ & $\beta$-lact. & $\alpha$-lact. & front \\
\hline \multicolumn{10}{|c|}{ Carpathian breed } \\
\hline Mean & 0.6925 & 2.705 & 2.568 & 14.300 & 30.560 & 15.408 & 17.898 & 13.988 & 1.908 \\
\hline $\begin{array}{c}\text { St. } \\
\text { deviation }\end{array}$ & 0.3074 & 0.3814 & 0.8420 & 1.392 & 2.676 & 1.938 & 1.885 & 0.8755 & 0.4430 \\
\hline Minimum & 0.3700 & 2.200 & 1.660 & 12.540 & 27.190 & 13.070 & 15.460 & 12.730 & 1.500 \\
\hline Maximum & 1.100 & 3.120 & 3.660 & 15.730 & 33.610 & 17.360 & 19.450 & 14.600 & 2.500 \\
\hline \multicolumn{10}{|c|}{ Alpine breed } \\
\hline Mean & 0.8025 & 4.003 & 2.600 & 14.935 & 25.993 & 12.308 & 23.848 & 13.980 & 1.398 \\
\hline $\begin{array}{c}\text { St. } \\
\text { deviation }\end{array}$ & 0.1497 & 0.4360 & 0.3755 & 0.9146 & 1.340 & 0.4691 & 0.5414 & 1.017 & 0.3721 \\
\hline Minimum & 0.6200 & 3.410 & 2.270 & 13.830 & 24.880 & 11.670 & 23.120 & 13.060 & 1.090 \\
\hline Maximum & 0.9800 & 4.350 & 2.940 & 16.050 & 27.930 & 12.800 & 24.410 & 15.040 & 1.890 \\
\hline
\end{tabular}

values of $17.19 \%$ in the first group of samples, and $24 \%$ in the second group. The last protein fraction recorded in the conducted investigations was $\alpha-L G$, protein with molecular weight of $14 \mathrm{kDa}$, which in this study showed the same percentage values for both groups investigated, respectively $13.98 \%$.

The characterization of identified fractions in protein profile of studied milk from those two goat breeds raised interest for many researchers. Lactoferrin is a glycoprotein with a complete sequence, which includes approximately 680 amino acid residues, varying from one species to another, presenting different structures of the glycan chain. This protein has a major role in iron binding and in maintaining haemoglobin in optimal parameters, with major implications for local defence of lactoferrin structures (Ramunno et $a l ., 2004)$. The $\alpha s 1-C N$ fraction is a protein formed of 199 amino acids, and for goat's there were identified 17 genetics variants (Ramunno et al., 2004). This protein has a low and inconstant level in milk, and sometimes it may be absent. It seems that this protein is responsible for producing some allergies in cow's milk case, including specific haplotypes (Olalla et al., 2009). 
Another specific milk protein fraction is $\alpha$ s2$\mathrm{CN}$, it is formed of 207 amino acids and it was noted in 9 genetic variants (Cosenza et al., 2005). It seems that it occurs in the transport of amounts of calcium and phosphorus. Micelles of these caseins transform milk into low viscosity liquid to prevent precipitation of these minerals within the mammary gland (Erhardt et al., 2002). The milk contains also $\beta$-casein, an important protein in terms of nutrition, as it was scientifically demonstrated that it can induce important allergies, being formed of 209 amino acids and identified 8 genetic variants (Caroli et al., 2006). The K-casein fraction formed of 169 amino acids, containing 16 polymorphic sites goats, 13 genetic variants and up to 3 mutation genes (Jann et al., 2004). Finally, a great importance should be attributed to $\beta$-lactoglobulin protein fractions, which is formed of 162 amino acids and has 2 genetic variants. The physiological role is not well known. It is assumed that this protein is involved in intestinal transport of retinol (vitamin A) because of sequence similarity with the proteins "retinolbinding". In humans, it is assumed that this protein might be the cause of food allergies (Yahyaoui et al., 2000; Andrei and Groza, 2010). The a-lactalbumin is a protein essential for the biosynthesis of lactose in the mammary gland. Due to its important role in milk synthesis, it is considered a valuable genetic marker for monitoring the milk production. From the structural point of view is a single-stranded polypeptide, with different number of cysteine residues (Andrei and Groza, 2010).

\section{CONCLUSION}

The ensemble of obtained results in this study reveals the existence of differences between protein profile of the milk from those two breeds, given by the increased proportions of $\beta$-lactoglobulin and immunoglobulin fractions in the Alpine goats' milk versus the Carpathian goats' milk, respectively $\beta$-casein, which is quantitatively more in Carpathian goats' milk. A simple comparative analysis of these differences reveals a higher potential of the mammary gland self-defence at Alpine breed goats compared to those of Carpathian breed.

\section{REFERENCES}

1. Andrei S (2006), Analytical methods used for milk proteins separation and identification. Bulletin USAMV Cluj Napoca series MV, 63:16-21

2. Andrei S, Pintea A, Bele C (2012), Veterinary Biochemistry - Practical work, Editura AcademicPres Cluj

3. Andrei S, GROZA IS (2010), Fiziologia si patologia glandei mamare la vaca, Editura AcademicPres Cluj

4. Ballabio C, Chessa S, Rignanese D, Gigliotti C, Pagnacco G, Terraccino L, et al., (2011). Goat milk allergenicity as a function of $\alpha$ S1-casein genetic polymorphism. Journal of Dairy Science ,Vol. 94, Issue 2: 998-1004

5. Bradford M (1976). A Rapid and Sensitive Method for the Ouantifiation of Microgram Quantities of Protein Utilizing the Principale of Orotein-Dye Binding. Analytical Biochemistry 72: 248-254

6. Caroli A, Chiatti F, Chessa S, Rignanese D, Bolla P, Pagnacco G (2006). Focusing on goat casein complex. J. Dairy Sci. 89: 3178-3187

7. Ceballos L, Morales E, Adarve G, Castro J, Martinez L, et al., (2009). Composition of goat and cow milk produced under similar conditions and analyzed by identical methodology. J Food Comp Anal 22: 322-329.

8. Cosenza G, Pauciullo A, Gallo D, Berardino D, Ramunno L (2005). A Sspl PCR-RFLP detecting a silent allele at the goat CSN2 locus. J. Dairy Sci. 72:456-459.

9. Drewnowski A and Fulgoni V (2008). Nutrient profiling of foods: creating a nutrientrich food index. Nutr Rev 66: 23-39.

10. Erhardt G, Jager S, Budelli E, Caroli A (2002). Genetic polymorphism of goat aS2-casein (CSN1S2) nd evidence for a further allele. Milchwissenschaft 57:137-140.

11. Gill R, Howard W, Leslie K, Lissemore K (1990). Economics of mastitis control, J Dairy Sci., 73: 3340-3348.

12. Haenlein G (2004). Goat milk in human nutrition. Small Rum Res 51: 155-163.

13. Hinz K, O'Connor PM, Huppertz T, Ross RP, Kelly AL (2012). Comparison of the principal proteins in bovine, caprine, buffalo, equine and camel milk. J Dairy Res 79: 185-191.

14. Jann O, Prinzenberg E, Luikart G, Caroli A, Erhardt (2004). High polymorphism in the kappa-casei (CSN3) gene from wild and domestic caprine species revealed by DNA sequencing. J. Dairy Res. 71:188-195.

15. Korhonen H (2009). Milk derived bioactive peptides: From science to aplications. Journal of Functional Foods, 1:177-187.

16. Korhonen H and Pihlanto A (2001). Milk protein derived bioactive peptides novel opportunities for health promotion. IDF Bulletin 363:17-26.

17. Michel V (2001). Microbial flora of raw cow's milk and influence of the conditions of production, Academic Journals., pp. 575-591.

18. Murata M, Wakabayashi H, Yamauchi K, Abe F (2013). Identification of milk proteins enhancing the antimicrobial activity of lactoferrin and lactoferricin. J Dairy Sci 96: 4891-4898. 
19. Năsălean A, Stefănuţ C, Pall E, Someșan R, Ognean L (2015). Comparative Analysis of Fat and Protein Content in Milk from Alpine and Carpathian Goats, Bulletin UASVM Veterinary Medicine 72(2), 250-253.

20. Ognean L (2001). Configuraţia lactocitogramei la capră şi corelarea ei cu starea de sănătate a glandeimamare. Lucrări ştiinţifice Univ. De StiinţeAgricoleşiMedici năVeterinară "Ion Ionescu de la Brad" Iaşi, 44 (3), seriaMedicinăVeterinară, 258-264.

21. Olalla M, Ruiz-Lo'pez M, Navarro M, Artacho R, Cabrera C, et al., (2009). Nitrogen fractions of Andalusian goat milk compared to similar types of commercial milk. Food Chem 113: 835-838.

22. Park Y, Juarez M, Ramos M, Haenlein G (2007). Physicochemical characteristics of goat and sheep milk. Small Rum Res 68: 88-113.

23. Ramunno L, Cosenza G, Rando A, Illario R, Gallo D, Berardini D, Masina P (2004). The goat as1-casein gene: gebane structure and promoter analysis. Gene 334: 105111.
24. Roncada P, Piras C, Soggiu A, Turk R, Urbani A, et al., (2012). Farm animal milk proteomics. J Proteomics 75: 4259-4274.

25. Santos A, Dias A, Pinheiro JA (2010). Predictive factors for the persistence of cow's milk allergy. Pediatr Allergy Immu 21: 1127-1134.

26. Vargas M, Cha'fer M, Albors A, Chiralt A, Gonza'lezMartine'z C (2008). Physicochemical and sensory characteristics of yogurt produced from mixtures of cow's and goat's milk. Int Dairy J 18: 1142-1152.

27. Yadav J, Saurav P, Jyotsna K, Yashab K, Ajay K,Masih F, Masih H (2014). Comparative evaluation of pathogenic bacterial incidence in raw and pasteurized milk, International Journal of Engineering Science Invention, Volume 3 Issue 5, PP.11-20.

28. Yahyaoui M, Pena R, Sanchez A, Folch J (2000). Rapid communication: polymorphism in the goat betalactoglobulin proximal promoter region. Journal of Animal Science 78:1100-1101. 